\title{
Role of Goods and Services Tax in India's Economic Development
}

\author{
Gowtham Ramkumar, S. Chitra
}

\begin{abstract}
Indirect taxes are one of the sources of income for government. The indirect tax reforms played a major part in choosing the heading of financial development. Goods and Services tax is one of the noteworthy roundabout charge change in India. It was presented in India in July 1,2017. Numerous pre-GST execution investigate considers demonstrated that products and administrations charge will contribute to the financial development of the nation. Presently, it is nearly two a long time since the usage of GST. This inquire about consider looks for to ponder whether there's any relationship between merchandise and administrations charge and financial development. In arrange to ponder this relationship, GST turnover and GDP of India for these two a long time is considered. At last, the consider arrives at a significant conclusion and clearly clarifies the degree of impact of GST in Indian financial advancement.
\end{abstract}

Keywords : Goods and Services Tax, GST Turnover, Economic Development, Gross Domestic Product..

\section{INTRODUCTION}

$\mathrm{T}$ axes are the major source of revenue for government. They are helpful in financing public expenditures. The large amount of tax collected by the government is utilized for various social, economic reforms and development plans of the nation. The tax structures are supposed to reduce the tax payer's compliance cost, administrative cost and also reduce tax evasion. Taxes are considered to be an important decision making factor. For investors, they play a major role in deciding investment alternative. For companies, it plays a major role in production decision and investment decision. For households they play a major role in determining savings level and purchase decision. Taxes and taxation structure also a dominant role in deciding the growth of the economy. Net Household Item (GDP)'s components like utilization consumption, speculation consumption, government consumption, trades and imports are affected by the tax collection framework winning within the nation. Charges moreover play a major part in affecting the costs charged for the products and administrations. Assist it too plays a major part in choosing the standard of living of the individuals

Revised Manuscript Received on December 05, 2019.

* Correspondence Author

Gowtham Ramkumar*, Part-Time Research Scholar, Department of Commerce, Faculty of Science and Humanities, SRM Institute of Science and Technology, Chennai, India. Email ID: gr5013@srmist.edu.in

Dr. S. Chitra, Associate Professor and Head, Department of Commerce, Faculty of Science and Humanities, SRM Institute of Science and Technology, Kattankulathur, Chennai, India. within the nation. Charges impacts sends out and imports within the frame of cross border duties charged by the countries over the globe. The Roundabout charges plays a noteworthy part in deciding the direction of growth of the economy. Products and Administrations charge in India may be a goal based assess, presented with the objective of making India - a single common financial development. It is nearly 2 a long time since India presented this unused charge framework and it made critical affect on diverse segments of the economy. Goods and Services tax in India is identified with the following features

- It is a consumption based tax. As such tax accrues at the place of consumption rather the place of manufacturing.

- Dual GST is another feature. India basically has two forms of GST namely Central Goods and Services tax (CGST) and State Goods and Services Tax (SGST). In case of interstate transactions, Integrated Goods and Services Tax (IGST) is levied.

- Even barter and related transactions are also taxable under GST.

- Further, exports are zero rated.

- It avoids double taxation i.e. taxes on taxes.

- Input charge credit is another key characteristic of merchandise and administrations assess where charge required at each organize of generation is discounted within the ensuing stages of fabricating.

- In India, GST is levied in four slabs namely 5\%, $12 \%$, $18 \%$ and $28 \%$ respectively.

\section{REVIEW OF LITERATURE}

Govind Rao (2000) conducted a research study to analyze the reasons behind taxation reforms made by government in India. For this purpose, the study adopted various tax models suggested by prominent economists. The study observed that implementation tax reforms committee recommendations gave positive results in the form of appreciable increase in filing of income and corporate tax reforms in the country. The study concluded with a recommendation to crash multiple indirect tax system and suggested for a dual model of indirect taxes for the country.

Magu (2010) in their inquire about ponder relating to affect of coordinate and backhanded charges relationship with financial development found that import duty, extract obligation includes a negative and critical impact on the Kenya's financial advancement whereas salary assess emphatically impacts 
the financial development.

Rajeswari and Susai (2014) analyzed tax and GDP trend in the economy through their research study. The study also observed the tax buoyancy factor. The study concluded that tax contribution towards economic growth was consistent till 2008-2009. There was an impact of economic crisis on tax buoyancy which was enhanced in further years. However, the study established the fact that tax revenue share in GDP substantially reduced in the subsequent years. The study recommended increasing revenue from direct taxes rather than indirect taxes.

Subrahmanya and Urmi (2015) conducted to analyze the GDP of the economy with special reference to direct and indirect taxes. The study identified that short term customs duty and corporate taxes significantly contributed to the economic growth while excise duty negatively impact the economic growth. Further it was also found that income tax appears to have no affect on the financial development of the country.

Nishitha Guptha (2014) in her inquire about ponder concluded that products and administrations charge usage will offer different commercial benefits not given by different roundabout tax assessment framework. She assist expressed that products and administrations assess will contribute to the financial improvement within the long run and anticipated to advantage rural division, fabricating segments as well as Central and State governments in India.

Poonam (2017) in her consider expressed that merchandise and administrations charge execution is one of the critical tax assessment change that the country will witness within the later a long time. Conventional issues like twofold checking, cascading impacts will be killed with the presentation of merchandise and administrations assess. She encourage expressed that presentation of products and administrations will diminish the burden on shoppers 25 to $30 \%$, increment competitiveness and energize financial development.

Nitin Kumar (2014) in his paper entitled "Goods and Services Tax in India: A way forward" concluded that products and administrations assess will pulverize the existing the different tax collection framework and excepted to bind together the economy by collecting assess within the place of utilization instead of at the put of fabricating.

\section{STATEMENT OF THE PROBLEM}

This examination study looks to break down the effect of merchandise and enterprises charge on the financial improvement of India. The tax assessment framework impacts the monetary development of the country. Many research studies recognizes the connection among duties and monetary development. Some exploration concentrates even centered around how presentation of merchandise and ventures assessment will profit the monetary development. It has been a long time since the usage of merchandise and enterprises charge. In this manner it is the opportune time to break down whether GST has added to monetary improvement as proposed by different specialists. Henceforth this examination study is done.

\section{OBJECTIVES OF THE STUDY}

The various objectives of the study are as follows

- To understand the relationship between taxes and economic growth of the country.

- To study the impact of goods and services tax on the economic development of India

- To suggest measures to boost or accelerate the growth rate of Indian economy.

\section{RESEARCH METHODOLOGY}

The information required for this ponder is collected from both essential and auxiliary sources. The measurable plan utilized in this consider is Simple Regression Analysis. It is utilized to expect the estimation of a variable subordinate on the estimation of other variable. It moreover empower one to choose the common fit (alter clarified) of the show and the by and large commitment of each one of the markers to the all out change clarified.

\section{LIMITATIONS OF THE STUDY}

The various limitations of the study are as follows

- The study uses the secondary data. Therefore limitations of these sources apply to this study.

- The study deals with the data made available and therefore it may not judge the entire scenario.

\section{RESULTS AND DISCUSSIONS}

$\boldsymbol{H}_{0^{-}}$There is no significant relationship between GST and GDP of Indian Economy.

$\boldsymbol{H}_{I^{-}}$There is a significant relationship between GST and GDP of Indian Economy.

Table 1 showing the Coefficient tables of regression analysis

\begin{tabular}{|c|c|c|c|c|c|}
\hline \multicolumn{2}{|c|}{ Model } & \multicolumn{2}{|c|}{$\begin{array}{c}\text { Unstandardized } \\
\text { Coefficients }\end{array}$} & $\begin{array}{c}\text { Standardized } \\
\text { Coefficients }\end{array}$ & \multirow{2}{*}{ Sig. } \\
\cline { 3 - 5 } & B & Std. Error & Beta & \\
\hline \multirow{2}{*}{1} & (Constant) & 120.288 & .000 & & .000 \\
\cline { 2 - 5 } & $\begin{array}{c}\text { GST } \\
\text { Collection }\end{array}$ & 3.956 & .000 & 1.000 & .000 \\
\hline \multicolumn{7}{|c|}{ Dependent Variable: India GDP } \\
\hline
\end{tabular}

The above table 1 shows the regression co-efficient between goods and services tax and gross domestic product of the Indian Economy. The GDP of India is the dependent variable and GST collection is the independent variable. From the above table, the regression equation can be obtained as follows

$$
Y=120.288+3.956 X_{1}
$$

$\mathrm{Y}$ is the GDP of India and X1 indicates goods and services tax collected during the year. Thus based on the beta scores, it is clear that GST collection, in other words, GST turnover have positive relationship with

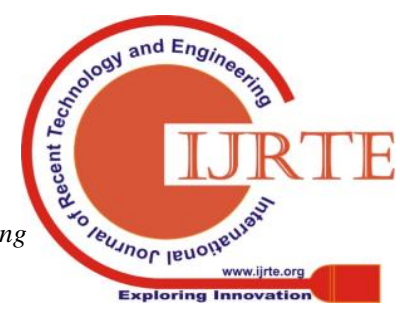


GDP of the Indian Economy. The GDP of India during 2017-2018 and 2018-2019 were Rs.131.80 lakhs crores and Rs.140.78 lakhs crores respectively.

The GST turnover by the government during 2017-2018 and 2018-2019 were Rs.2.91 lakhs crores and Rs.5.18 lakhs crores respectively. Thus there is a strong relationship between GDP of Indian Economy and GST collection. As the computed value 0.000 is less than the significance value at $1 \%$ level, the null hypothesis is rejected and alternate hypothesis is accepted. The Indian Economy is facing a gradual slowdown in the growth rate. This is due to economic implications of taxes on the economy. With higher tax rates on one side and supply of money in the economy becoming constant, the economy got adversely affected which is reflected in the performance of various sectors of the Indian Economy.

\section{CONCLUSION}

To finish up, taxes assume a noteworthy job in the choosing the development pace of the economy. Goods and services appears to have adversely affected the Indian Economy. This is because of quick changes in the expense paces of the economy. Since presentation of GST, different changes were brought by Government of India making it an experimentation procedure. Presently, the GST system has been streamlined. It will require some investment to examine how this streamlined instrument will profit over the long haul of the Indian Economy. GST if appropriately executed can make India a typical monetary market. To finish up, the examination empowered to get down to earth contact with the point and saw how expenses impact financial development of a nation.

\section{SUGGESTIONS}

The following are the suggestions made by this research study

1. Tax concession and Tax subsidization can accelerate the growth rate of the economy.

2. To reap the fruits of GST, $28 \%$ slab should be abolished.

3. Efforts should be taken to increase money supply among people in the country. This can be done by reducing the direct taxes on the income earners.

4. The benefits of composition scheme should be communicated to small businesses so that GST does adversely impact them.

5. Finally, steps should be taken to shift the Service sector dependent economy to manufacturing sector dependent economy.

\section{REFERENCES}

1. Rao Govinda (2000), Tax Reform in India: Achievements And Challenges, Asia-Pacific Development Journal, Vol 7, No2, December.

2. Magu CyrusMuriithi(2013), The Relationship between Government Revenue and Economic Growth in Kenya, October 2013(A research Project) retrieved from http://erepository.uonbi.ac.ke/bitstream/handle/11295/58499/Magu_Eco nomic\%20Growth\%20.pdf? sequence $=3$

3. Rajeswari and Susai Mary(2014), The Trend And Pattern of Income Taxation in India, International Journal of Business and Administration Research Review, Vol 2,Issue -5 April June.
4. Subrahmanya.V and Urmi (2015), The impact of taxation on economic growth in India : A disaggregated approach using the ARDL bounds test to co-integration, International Journal of Accounting and Research studies, Volume $\quad 5 \quad$ (1) (2017)16-21. https://www.sciencepubco.com/index.php/IJAES/article/view/7040

5. Kumar, Nitin. Goods and Services Tax in India: A Way Forward. Global Journal of Multidisciplinary Studies. 2014; 3(6):216-225.

6. Gupta, Nishita. Goods and Services Tax: Its implementation on Indian economy: International

7. Research Journal of Commerce, Arts and Science. 2014; 5(3):126-133.

8. Poonam M. Goods and Services Tax in India: An Introductory Study, International Journal of Science Technology and Management. 2017; 6(1):101-109.

\section{AUTHORS PROFILE}

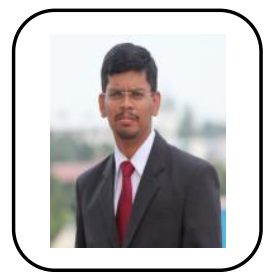

Mr. Gowtham Ramkumar, is a part time Research Scholar at SRM Institute of Science and Technology, Kattankulathur Chennai. He also works as Assistant Professor in the Department of Commerce (Aided), Madras Christian College where he pursed his both Under graduation and Post-Graduation. His area of research interest includes Taxation, Accounting \& Finance and Management. He has received two best paper awards in both the national conferences in which he had presented papers. $\mathrm{He}$ also serves as reviewer of notable national and international journals. Further, he is also a life member of many research promoting and academic organizations. As a young faculty and research scholar, he has 6 citations to his profile and published around 30 papers in national journals. He is also providing statistical assistance for data analysis using SPSS and AMOS.

Dr. S. Chitra, works as Associate Professor and Head at Department of

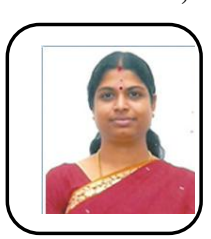
Commerce at SRM Institute of Science and Technology, Kattankulathur, Chennai. Her area of interest includes Finance, Human Resource Management, Law and Marketing. She also organized many conferences and seminars. She is also serving as Academic Council member and Board of Studies member for many years. She has further presented and published more than 30 papers in reputed national and international journals. In the year 2015-2016, She received Best Faculty Award from Cognizant Technology Solutions. 